\title{
Defect in the Membrane Expression of High Affinity 72-kD Fc $\gamma$ Receptors on Phagocytic Cells in Four Healthy Subjects
}

\author{
Jan L. Ceuppens," Miren L. Baroja," Frieda Van Vaeck," and Clark L. Anderson" \\ *Division of Clinical Immunology, Department of Medicine, University of Leuven, 3000 Leuven, Belgium; \\ and the ${ }^{\ddagger}$ Department of Medicine, The Ohio State University, Columbus, Ohio 43210
}

\begin{abstract}
Three different receptors for the Fc portion of IgG (FcR) have been characterized on human leukocytes. We have identified four healthy members of one family, whose blood phagocytic cells lack functional $72 \mathrm{kD}$ high-affinity FcRI. Their monocytes were unable to bind the Fc portion of mouse (m)-IgG2a and of monomeric human IgG, and they were unreactive with two anti-FcRI monoclonal antibodies. Thus, FcRI is either absent, expressed at very low density, or is so structurally altered as to be unable to bind both its ligand and the anti-FcRI antibodies. The failure to bind the Fc portion of mIgG2a underlies the previously reported inability of these monocytes to support T cell mitogenesis on OKT3 stimulation. FCRI was not inducible upon incubation of their monocytes or neutrophils in gamma interferon. However, their monocytes were able to bind aggregated human IgG, and to phagocytose IgG-coated particles in vitro. Both functions could be blocked with a monoclonal antibody to the 40-kD low-affinity FCRII and therefore apparently were mediated exclusively through FcRII. This also demonstrates that FcRII can mediate phagocytosis independently. Despite the FcRI defect, these subjects had no circulating immune complexes, no evidence of autoimmune pathology and no increased susceptibility to infections.
\end{abstract}

\section{Introduction}

Three distinct types of $\mathrm{Fc}$ receptors for $\mathrm{IgG}(\mathrm{FcR})^{1}$ have been identified on human leukocytes (for review see 1). A high affinity receptor $(\mathrm{FcRI})$ of $72 \mathrm{kD}$ is present on monocytes and macrophages (2-6). Neutrophils express this receptor after overnight incubation in gamma-interferon (7). A low affinity FcR (FcRII) of $40 \mathrm{kD}$ (the CDw32 antigen) has a broader range of cellular expression, being present not only on mono-

Address reprint requests to Dr. J. L. Ceuppens, Laboratory of Clinical Immunology, University Hospitals, Capucienenvoer 33, B-3000 Leuven, Belgium. Dr. Baroja is on leave from the Centro Nacional de Enfermedades Reumaticas, Caracas, Venezuela.

Part of this work has been presented as a poster at the National Meeting of the American Rheumatism Association, Washington, DC, June 1987 and as an oral presentation at the First International Waaler Conference, December 1987, Bergen, Norway.

Received for publication 29 September 1988 and in revised form 10 February 1988.

1. Abbreviations used in this paper: FcR, Fc receptor for IgG; HuIgG, human IgG; Hu-RBC, human red blood cells; mIgG, murine IgG.

J. Clin. Invest.

(c) The American Society for Clinical Investigation, Inc.

0021-9738/88/08/0571/08 \$2.00

Volume 82, August 1988, 571-578 nuclear phagocytes but also on granulocytes, platelets, and B-lymphocytes $(4,8,9)$. A third type of FcR (FcRIII) (the CD16 antigen) has a molecular weight from 50 to $70 \mathrm{kD}$, is expressed by macrophages (but not monocytes), neutrophils, eosinophils (sparce), and subsets of lymphocytes (T-gamma cells and natural killer cells) (10-13). The 72-kD FcR binds monomeric human (Hu) IgG1 and IgG3 with a $K_{\mathrm{a}}$ of $10^{8}-10^{9}$ $M^{-1}$, and $1-4 \times 10^{4}$ receptors are present per monocyte $(5,6)$. In contrast HuIgG binds to FcRII only when it is present as a complex (either soluble complexes or IgG-coated particles) (4, 14). The specificity of the monocytic receptors for murine (m) subclasses is quite distinctive. FcRI binds mIgG2a and mIgG3 with high affinity $(4,15)$, while FcRII binds mIgG1 and mIgG2b, although to be detected, binding must be enhanced by using low ionic strength conditions or ligand complexes (4, 14, 15).

FcRs are important for the clearance of immune-complexes and for internalization of IgG-coated cells or organisms. Defective FcR function has been associated with certain HLA-haplotypes and with immune complex disease susceptibility (16-18). FcR triggering can stimulate cell metabolism, e.g., chemiluminescence of phagocytic cells (3). Moreover, FcRs might be important for antigen presentation $(19,20)$, and FcRs on phagocytic cells and NK cells are essential for extracellular killing in antibody-dependent cellular cytotoxicity $(21,22)$. No functional differentiation between the distinct types of FcRs expressed on the same cell-type has been found yet and the relative importance of the three FcRs in mediating immunophagocytosis is not known.

We describe four healthy subjects, belonging to one kindred, apparently lacking functional FcRI. We have previously reported on these subjects as "OKT3 nonresponders," indicating the lack of proliferative $T$ cell responses to the monoclonal anti-CD3 antibody OKT3 (and to other anti-CD3 antibodies of the mIgG2a subclass) in cultures of peripheral blood mononuclear cells (PBMC) $(23,24)$. Unresponsiveness was observed in four among the seven children of one family and was not related to a particular HLA-haplotype (23). The identification of these subjects was a fortuitous one, made while we were determining normal values for proliferative responses of PBMC to OKT3 on a large series of healthy donors. $T$ cell stimulation in this system requires interactions of antiCD3 with CD3 on the T cell membrane and with monocyte FcRs $(24,25)$. We reported that monocytes from nonresponders were unable to bind the Fc part of mIgG2a (24) and that this inability to bind mIgG2a underlies the inability of the monocytes to support mIgG2a anti-CD3-induced T-cell mitogenesis. We have now further explored this lack of mIgG2a binding to monocytes, and report here that it is based on a new and interesting defect of FcRI expression. The absence, low density expression, or afunctionality of this receptor is not associated with any disease. The significance of the FcRI defect remains to be determined. 


\section{Methods}

Subjects. The four subjects, previously indentified as "OKT3 nonresponders" $(23,24)$, are four sisters, aged $32,27,26$, and 19 years. They are clinically healthy and have no history of repeated or protracted infections, and no clinical features indicating autoimmune or immune complex pathology. There is no evidence for consanguinity of the parents. Control subjects (OKT3-responders) were healthy, aged 20-50. Blood was drawn after informed consent.

Monoclonal antibodies. The murine monoclonal anti-CD3 antibody OKT3 (unlabeled and FITC-conjugated), was purchased from Ortho Diagnostics (Beerse, Belgium). The antibody was centrifuged at $100,000 \mathrm{~g}$ or $30 \mathrm{~min}$ before use in immunofluorescence experiments. Monoclonal antibodies to FcRs were previously described $(3,4,12)$. Ab 32,2 is a mIgG1 antibody against FcRI. A second mIgGl antibody against FCRI (Ab 44.1) detecting a different epitope, was a gift from $\mathrm{Dr}$. P. Guyre (Dartmouth Medical School, Hanover, NH). Ab IV.3 is a mIgG2b antibody against FcRII. Hybridoma supernatants were used for all the experiments. It has previously been excluded that these antibodies bind to FcRs through their Fc part (4). Anti-Leu 11b (an IgM antibody against FcRIII) and OKM1 (an mIgG2b antibody against the $\mathrm{C} 3 \mathrm{bi}$ receptor [CD11b]), were purchased from Becton Dickinson (Erembodegem, Belgium) and Ortho Diagnostics (Beerse, Belgium), respectively $(12,26)$.

Other reagents. Human Cohn fraction II (Sigma Chemical Co., St. Louis, MO) was used as a source of HuIgG. FITC-conjugated HuIgG was purchased from Cappel Laboratories (Malvern, PA). A 1-mg/ml solution of both preparations was made up in PBS pH 7.2. To prepare monomeric IgG, the solution was centrifuged at $100,000 \mathrm{~g}$ for $30 \mathrm{~min}$ and only the top two-thirds of the supernatant was used. To prepare aggregated IgG the solution was heated at $64^{\circ} \mathrm{C}$ for $30 \mathrm{~min}$ and centrifuged at $20,000 \mathrm{~g}$ for $30 \mathrm{~min}$ to remove insoluble aggregates. Recombinant human gamma-interferon was purchased from Janssen Chimica (Beerse, Belgium).

Cell separation. PBMC were isolated from heparinized blood on Ficoll-Hypaque (density 1.077) gradients. T cells and non-T cells were separated by rosetting with 2-aminoethylisothiouronium bromide (AET)-treated sheep red blood cells (SRBC) as reported (27). Nonrosetting cells contained less than 3\% OKT3-reactive cells, were $>50 \%$ peroxidase-positive, and were used as a source of monocytes. Neutrophils were isolated from the pellet of the Ficoll-Hypaque gradients. Red blood cells (RBC) were lysed with ammonium chloride.

Cell cultures. For antigenic stimulation, PBMC were resuspended in culture medium of RPMI 1640 (Gibco, Gent, Belgium) containing 2 $\mathrm{mM} \mathrm{L-glutamine,} \mathrm{penicillin}(100 \mathrm{U} / \mathrm{ml})$, streptomycin $(100 \mu \mathrm{g} / \mathrm{ml})$ and supplemented with 5\% normal human serum (NHS). Cell concentration was $10^{6} / \mathrm{ml}$, and $200 \mu$ l cell suspension was cultured in roundbottom microculture plates. Antigens were added at previously determined optimal concentrations: tetanus toxoid (Wyeth, Marietta, PA) 1 $\mathrm{Lfu} / \mathrm{ml}$; streptokinase-streptodornase (Lederle Laboratories, Wayne, NJ) $50 \mathrm{U} / \mathrm{ml}$; Candida-antigen (Haarlem Allergen Laboratories, The Netherlands) $50 \mu \mathrm{g} / \mathrm{ml}$; influenza antigen (Duphar, Brussels, Belgium) $1 / 2,000$ final dilution. All cultures were performed in quadruplicate at $37^{\circ} \mathrm{C}$ in a humidified $5 \% \mathrm{CO}_{2}$ atmosphere. After $6 \mathrm{~d}$ of culture, cells were pulsed with $1 \mu \mathrm{Ci}$ of $\left[{ }^{3} \mathrm{H}\right]$ thymidine (specific activity $2 \mathrm{Ci} / \mathrm{mmol}$, Amersham Ltd., Amersham, UK) and $8 \mathrm{~h}$ later, cells were harvested with a MASH II and radioactivity on the filter papers was counted. To study the effect of gamma interferon on FcR expression, monocytes and neutrophils were cultured at a concentration of $10^{6}$ cells $/ \mathrm{ml}$ in Teflon jars, in culture medium containing $12 \%$ NHS and $5 \times 10^{-5} \mathrm{M}$ mercaptoethanol, with or without recombinant gamma interferon $(100 \mathrm{U} / \mathrm{ml})$.

Immunofluorescence. To study the binding of IgG to monocyte FcRs, non-T cells $\left(0.5 \times 10^{6}\right)$ in a $50-\mu$ l vol of PBS with $1 \%$ BSA (pH 7.4) were incubated with the ligand for $30 \mathrm{~min}$ at $4^{\circ} \mathrm{C}$. This was either monomeric OKT3-FITC $(0.5 \mu \mathrm{g})$, monomeric HuIgG-FITC (2 and 0.5 $\mu \mathrm{g})$ or aggregated HuIgG-FITC $(8,2$, and $0.5 \mu \mathrm{g})$ in a $50-\mu \mathrm{l}$ volume. This corresponds to final concentrations of the ligand of 80,20 , and 5 $\mu \mathrm{g} / \mathrm{ml}$. After incubation, cells were washed twice in PBS-BSA, and fixed in $1 \%$ paraformaldehyde. In some experiments, in order to block the binding of FITC-conjugated IgG to FcRs, cells were preincubated with a fivefold excess of unlabeled HuIgG or of mIgG2a or with $10 \mu \mathrm{l}$ of monoclonal anti-FcRII Ab IV.3 (at $4^{\circ} \mathrm{C}$ for $30 \mathrm{~min}$ ), before the FITC-conjugated ligand (OKT3-FITC or HuIgG-FITC) was added.

To detect autologous cytophilic IgG on monocytes, freshly isolated non-T cells in $50 \mu$ l of PBS-BSA were incubated at $4^{\circ} \mathrm{C}$ for $30 \mathrm{~min}$ with $50 \mu$ l of FITC-conjugated $\mathrm{F}\left(\mathrm{ab}^{\prime}\right)_{2}$ fragments of goat anti-HuIgG (1/40) (Tago, Burlingame, CA). After washing, cells were fixed in paraformaldehyde as described above.

For staining with monoclonal antireceptor antibodies, non-T cells or neutrophils in a $50 \mu \mathrm{l}$ volume of PBS-BSA were incubated with $10 \mu \mathrm{l}$ of monoclonal antibody 32.2, 44.1, IV.3 (diluted 1/10), OKM1 (20 $\mu \mathrm{g} / \mathrm{ml})$, anti-Leu $1 \mathrm{lb}(50 \mu \mathrm{g} / \mathrm{ml})$, or a control monoclonal antibody of the mIgGI subclass (anti-Leu 4) $(20 \mu \mathrm{g} / \mathrm{ml}$ ) (as a control for nonspecific binding). Cells were washed twice, and then further incubated with FITC-conjugated $\mathrm{F}\left(\mathrm{ab}^{\prime}\right)_{2}$ fragments of goat anti-mIgG or of anti-mIgM (for staining with anti-Leu 11b) (Tago) $(50 \mu \mathrm{l}$ of a 1/40 dilution in PBS-BSA) for $30 \mathrm{~min}$ at $4^{\circ} \mathrm{C}$. After two washings, cells were fixed in $1 \%$ paraformaldehyde.

Before analysis, cells were washed and resuspended in one $\mathrm{ml}$ of PBS. They were then analyzed on a FACS-Star (Becton-Dickinson). The gating was set around the monocyte or neutrophil population and 5,000 cells were analyzed for fluorescence.

Binding of radiolabeled $\mathrm{HuIgG}$. Monomeric $\mathrm{HuIgG}$ (Cohn fraction II, $12 \mathrm{mg} / \mathrm{ml}$, centrifuged for $30 \mathrm{~min}$ at $100,000 \mathrm{~g}$ ) was labeled with ${ }^{125} \mathrm{I}$ by the chloramine $\mathrm{T}$ method to a specific activity of $4 \mu \mathrm{Ci} / \mu \mathrm{g}$. The solution was centrifuged at $20,000 \mathrm{~g}$ to remove insoluble aggregates, the concentration was adjusted to $20 \mu \mathrm{g} / \mathrm{ml}$ in PBS-BSA, and a twofold serial dilution was made. E-rosette negative cells (at a concentration of 10 to $15 \times 10^{6}$ peroxidase-positive cells per $\mathrm{ml}$ ) in medium with $50 \%$ FCS were preincubated in plastic tubes at $4^{\circ} \mathrm{C}$ with Ab IV.3 (in order to block FcRII). We then added ${ }^{125} \mathrm{I}-\mathrm{IgG}$ in final concentrations of 6 to $0.37 \mu \mathrm{g} / \mathrm{ml}$ to the cell suspensions, and further incubated the mixture for $45 \mathrm{~min}$ at $4^{\circ} \mathrm{C}$. Final cell concentration was $3-4.5 \times 10^{6}$ monocytes $/ \mathrm{ml}$. To determine nonspecific binding of ${ }^{125} \mathrm{I}-\mathrm{IgG}$, part of the cells were incubated with cold IgG $(6 \mathrm{mg} / \mathrm{ml})$ before the radiolabeled ligand was added. Nonspecific binding represented $<0.01 \%$ of the total radioactivity. After extensive washing, radioactivity bound to the cells was determined.

Rosetting with anti-D coated human $R B C$. Human D-positive RBC were sensitized with human anti-D antiserum (Ortho Diagnostics) and resuspended as a $1 \%$ solution in HBSS. $200 \mu \mathrm{l}$ of the suspension was mixed with $100 \mu$ l of E-rosette-negative cells $\left(1 \times 10^{7}\right.$ cells $\left./ \mathrm{ml}\right)$, centrifuged at $100 \mathrm{~g}$ for $5 \mathrm{~min}$, and incubated at $4^{\circ} \mathrm{C}$ for $60 \mathrm{~min}$. In some experiments the E-rosette negative cells were preincubated with $20 \mu \mathrm{l}$ of Ab IV.3 to block FcRII. After gentle resuspension, the number of rosette-forming monocytes was counted microscopically in a hemocytometer.

Monocyte phagocytosis assay. FcR-mediated phagocytosis by monocytes was evaluated by an assay similar to the one reported by Salmon et al. (17). SRBC $\left(10^{8}\right.$ cells $\left./ \mathrm{ml}\right)$ were sensitized with a maximal subagglutinating dose of rabbit anti-SRBC antiserum (Behringwerke, Marburg, FRG). In some experiments, a twofold serial dilution of the antiserum was used to prepare SRBC that were suboptimally opsonized. To the mixture of SRBC and antiserum, $50 \mu \mathrm{Ci}$ of ${ }^{51} \mathrm{Cr}$ was added. After a $1-\mathrm{h}$ incubation at $37^{\circ} \mathrm{C}, \mathrm{SRBC}$ were washed in PBS and resuspended in culture medium with $10 \%$ FCS at a concentration of $10^{8} / \mathrm{ml}$. The FCS used was heat-inactivated and absorbed with SRBC. $100-\mu 1$ samples of PBMC or E-rosette negative cells (adjusted to a concentration of $5 \times 10^{6}$ peroxidase-positive cells per $\mathrm{ml}$ in medium with $10 \%$ FCS) were combined with $200 \mu$ l containing varying numbers of ${ }^{51} \mathrm{Cr}$ labeled SRBC, either nonsensitized or sensitized with anti-SRBC antibodies. This resulted in monocyte/erythrocyte ratios of $1 / 10,1 / 20$, and $1 / 40$. The mixture was centrifuged for $3 \mathrm{~min}$ at 1000 $\mathrm{rpm}$ and incubated at $37^{\circ} \mathrm{C}$ for $1 \mathrm{~h}$. SRBC were then lysed with ammonium chloride in Tris buffer. The remaining cells were washed four 
times, and the resulting sediment was counted in a gamma counter (Packard Instruments, Inc., Downers Grove, IL) to determine mononuclear cell-associated ${ }^{51} \mathrm{Cr}$. Results are expressed as the mean number of SRBC phagocytosed per monocyte per hour, calculated after subtraction of the counts in the unopsonized SRBC control.

Other immunological tests. Antinuclear and antitissue antibodies in serum were measured with standard indirect immunofluorescent techniques on Hep- 2 cells and on frozen tissue sections, respectively (28). Serum immune-complexes were detected by binding to solidphase $\mathrm{Clq}$ and monoclonal rheumatoid factor ( $\mathrm{mRF}$ ) as previously reported (29). Serum immunoglobulines (A, $G$ and $M$ ) were measured with a standard nephelometric immunoassay (Hyland Travenol Laboratories, Costa Mesa, CA). In vivo specific antibody production was studied by immunization with hepatitis B-surface antigen. Three injections of the commercial Pasteur vaccine (Hevac B) were given intramuscularly with a 1-mo interval, and a fourth (booster) injection was given 1 yr later. Antibody levels were determined with the commercially available RIA (Abbott Laboratories, North Chicago, IL).

\section{Results}

Nonresponder monocytes do not bind monomeric mIgG2a or HuIgG. We have reported (24) that monocytes from "OKT3nonresponders" are unable to bind the Fc part of mIgG2a in an indirect immunofluorescence assay. We reexamined the FcR binding of mIgG2a to the monocytes with monomeric FITC-conjugated OKT3. Responder monocytes but not nonresponder monocytes were able to bind OKT3-FITC (not shown). Preincubation with unlabeled mIgG2a completely inhibited the binding of OKT3-FITC to the responder monocytes. In view of the reported specificity of the two distinct monocyte FcRs for mIgG subclasses (FcRI binds mIgG2a and FcRII binds mIgGi and $\mathrm{mIgG} 2 \mathrm{~b}$ ) the results suggested that the defect in nonresponder-monocytes is at the level of FcRI. We also studied the interaction of monocytes with HuIgG. We first incubated the cells with FITC-conjugated HuIgG. Monomeric HuIgG-FITC bound to responder monocytes, but not to nonresponder monocytes (Fig. 1). Monomeric HuIgG has been shown to bind to FCRI only (1-6), and the lack of binding to nonresponder monocytes thus further argues for a defect of FcRI expression. Both responder and nonresponder monocytes were able to bind aggregated HuIgG-FITC (Fig. 1). However, when the cells were incubated with decreasing doses of this ligand, the capacity of nonresponder monocytes to bind aggregated HuIgG-FITC was found to be lower than for responder monocytes (Fig. 1). Binding of aggregated HuIgGFITC was blocked by unlabeled aggregated HuIgG (not shown). Binding of aggregated HuIgG-FITC to nonresponder monocytes was also blocked with the anti-FcRII monoclonal antibody IV.3 (which has been shown to block the ligand interaction of FcRII (4)) (Fig. 2). In contrast, Ab IV.3 only partially reduced the binding of aggregated HuIgG-FITC to responder monocytes. These results thus indicate that the binding of aggregated HuIgG to nonresponder monocytes is mediated exclusively through FcRII. Lack of binding of aggregated HuIgG to nonresponder monocytes in the presence of Ab IV.3 makes it unlikely that nonresponder subjects have a variant FcRI with low affinity for IgG. To detect low density expression of FCRI, a radiolabeled ligand binding assay was also used. Cells from two responders and two nonresponders were first incubated with AbIV.3 to block FcRII and then incubated with ${ }^{125} \mathrm{I}$-HuIgG in concentrations ranging from 6 to $0.37 \mu \mathrm{g} / \mathrm{ml}$. Nonspecific binding was determined by preincubation with excess cold IgG. At the highest concentration of
A CONTROL SUBJECT
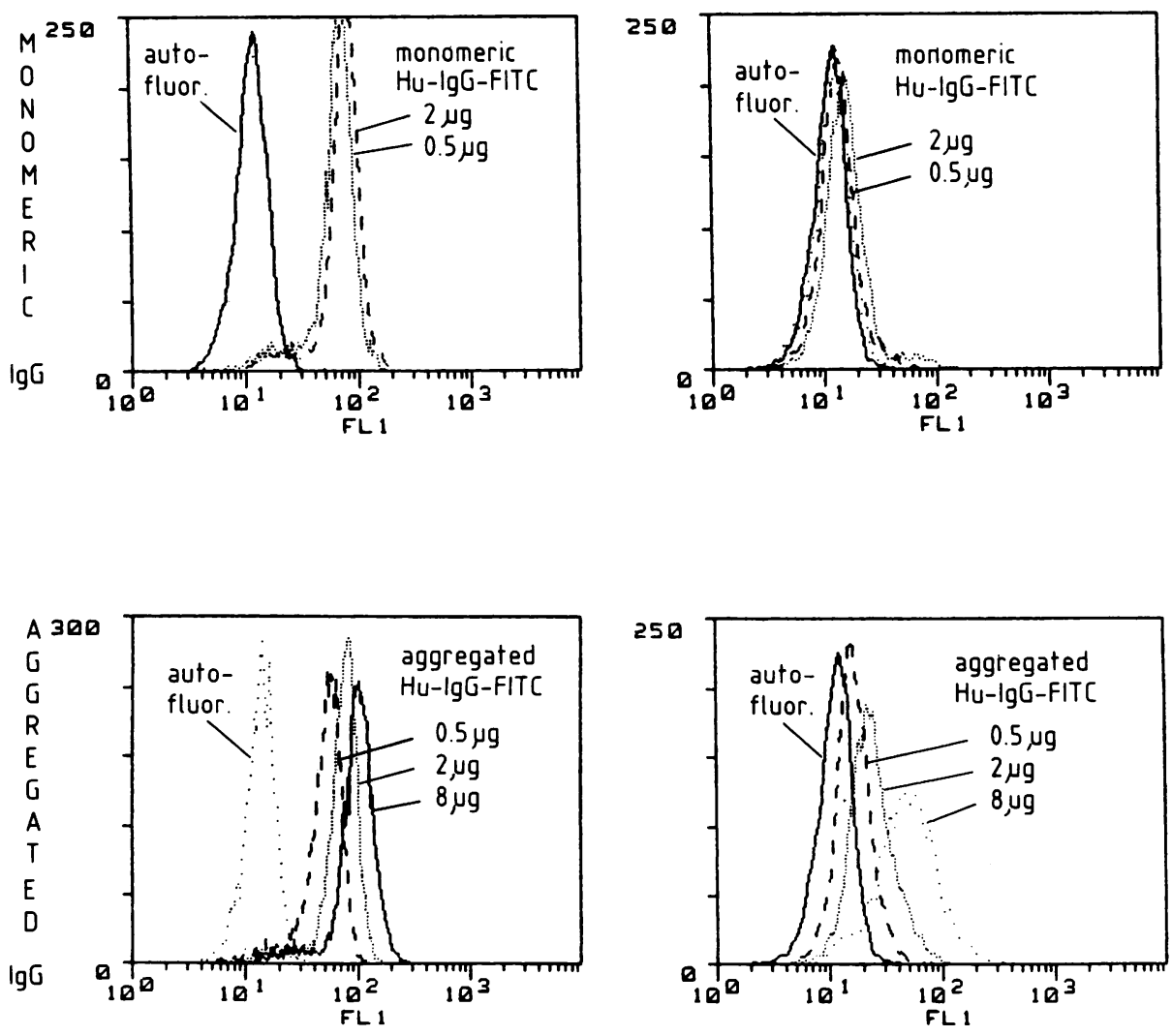

Figure 1. Binding of FITC-conjugated monomeric and aggregated $\mathrm{HuIgG}$ to monocytes. E-rosette-negative cells from controls (responders) $(A)$ or nonresponders $(B)$ were incubated in PBS-BSA, alone (autofluorescence), with 0.5 or $2 \mu \mathrm{g}$ of monomeric HuIgGFITC or with $0.5,2$, or $8 \mu \mathrm{g}$ of aggregated HuIgG-FITC in a total volume of $100 \mu \mathrm{l}$. This corresponds to final concentrations of the ligand of 5,20 , and $80 \mu \mathrm{g} / \mathrm{ml}$. After $30 \mathrm{~min}$ incubation at $4^{\circ} \mathrm{C}$, cells were washed twice and analyzed on a FACS. Forward and rightangle scatter gatings of the instrument were set to select monocytes and $\mathbf{5 0 0 0}$ cells were analyzed for fluorescence. Cell number is in the $y$ axis and fluorescence intensity in the $x$ axis. Results presented on this and the following five figures are representative for experiments on four nonresponders and six responders. 


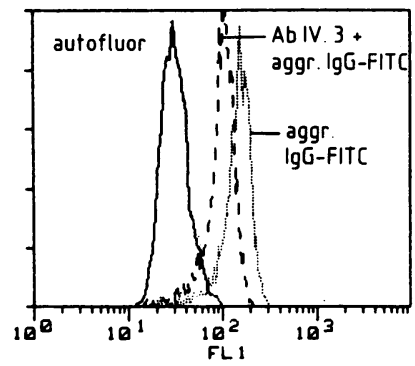

B $\mathrm{OKT}_{3}$-NONRESPONDER

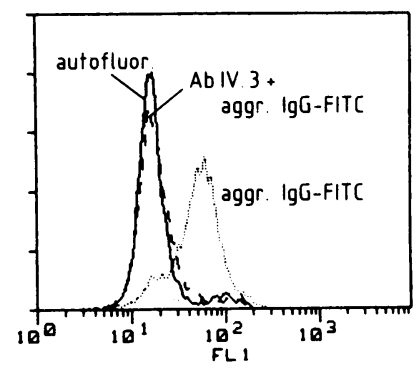

Figure 2. Effect of anti-FcRII monoclonal antibody (IV.3) on binding of aggregated HuIgG-FITC to monocytes. E-rosette-negative cells from controls (responders) $(A)$ or OKT3-nonresponders $(B)$ were incubated in PBS-BSA, alone or with $10 \mu$ l of Ab IV.3 (hybridoma supernatant) for $30 \mathrm{~min}$ at $4^{\circ} \mathrm{C}$, before aggregated HuIgG-FITC $(8 \mu \mathrm{g})$ was added (total volume $110 \mu \mathrm{l}$ ). After a further incubation at $4^{\circ} \mathrm{C}$ for $30 \mathrm{~min}$, cells were washed twice and analyzed on a FACS as explained in the legend to Fig. 1. Preincubation with Ab IV.3 blocks the binding of aggregated HuIgG-FITC to nonresponder monocytes, but not to responder monocytes.

${ }^{125} \mathrm{I}-\mathrm{HuIgG}, 5100$ and 8,100 IgG molecules were bound per responder monocyte. The counts per minute bound to the nonresponder monocytes were $<6 \%$ of the counts per minute bound to the responder monocytes. Low density expression of FcRI on nonresponder monocytes is therefore very unlikely.

The presence of autologous cytophilic IgG on freshly isolated monocytes was studied by immunofluorescence with FITC-conjugated $\mathrm{F}\left(\mathrm{ab}^{\prime}\right)_{2}$ fragments of goat anti-HuIgG. While cytophilic IgG was present on freshly isolated monocytes from all responder subjects, nonresponder monocytes lacked any detectable cytophilic autologous IgG (Fig. 3). These results excluded the possibility that FcRI on nonresponder monocytes was blocked with immune complexes.

Nonresponder monocytes do not form rosettes with anti-D coated human red blood cells $(\mathrm{Hu}-\mathrm{RBC})$. Hu-RBC coated with human anti-D antibodies have been shown to form rosettes with U937 cells and monocytes through binding to FcRI (4, 30). Lack of binding to FcRII is apparently due to the low surface density of the D-antigen. The assay was carried out with E-rosette negative cells from two responders and two nonresponders. A few monocytes (8 and 9\%) from the two
A CONTROL SUBJECT

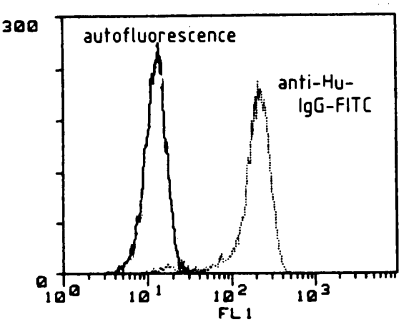

B $\mathrm{OKT}_{3}$-NONRESPONDER

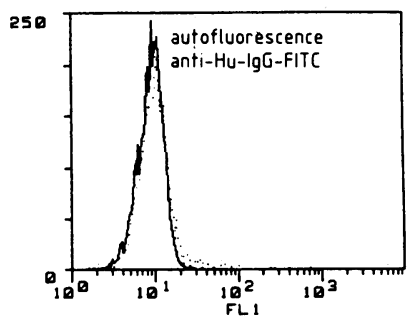

Figure 3. The presence of autologous cytophylic IgG on monocytes. Freshly isolated E-Rosette-negative cells from control (responder) subjects $(A)$ or nonresponders $(B)$ were incubated at $4^{\circ} \mathrm{C}$ for 30 minutes in PBS-BSA, alone (autofluorescence) or with FITC-conjugated $F\left(a b^{\prime}\right)_{2}$ fragments of goat-anti-HulgG. After washing, immunofluorescence on the monocytes (as compared to autofluorescence) was analyzed on a FACS. nonresponders formed poor rosettes ( 3 to $5 \mathrm{RBC} /$ monocyte) with the $\mathrm{Hu}-\mathrm{RBC}$, and this was blocked by preincubation with Ab IV. 3 to 3 and $2 \%$, respectively. The majority of responder monocytes formed rosettes with more than $5 \mathrm{RBC} /$ monocyte (69\% in donor 1 and $60 \%$ in donor 2 ) and this was only partially reduced (to $50 \%$ rosettes in both donors) by preincubation with Ab IV.3.

Nonresponder monocytes do not react with anti-FcRI antibodies. We analyzed the expression of FcRI on monocytes with two monoclonal antibodies against epitopes on FcRI (Ab 32.2 and 44.1) in an indirect immunofluorescence assay. None of the nonresponder monocytes reacted with these two antiFcRI antibodies either alone or combined, while all responder monocytes did (Fig. 4). These results indicate that nonresponder monocytes either do not express FcRI, or express FcRI below the level of detection of our assay, or that they express an altered FcRI, which does not express the epitopes recognized by $\mathrm{Ab} 32.2$ and 44.1. The receptor for $\mathrm{C} 3 \mathrm{bi}$ on leucocytes (detected with monoclonal antibody OKM1), was found to be present in normal density on the monocytes and neutrophils from nonresponders. Similarly, a normal density of FcRIII was detected on neutrophils and NK-cells with the monoclonal antibody anti-Leu $11 \mathrm{~b}(12)$. Monocytes from both responders and nonresponders lacked FcRIII. Both neutrophils and monocytes normally expressed the FcRII as detected with Ab IV.3 (not shown).

Gamma interferon does not induce FcRI expression on nonresponder monocytes or neutrophils. Gamma interferon has been shown to enhance the expression of FcRI on human monocytes $(7,31)$. We therefore cultured E-rosette-negative cells $\left(10^{6} / \mathrm{ml}\right)$ for $48 \mathrm{~h}$ in Teflon jars, with or without gamma interferon $(100 \mathrm{U} / \mathrm{ml})$. Cells were then stained with the antiFcRI antibodies (Ab 32.2 and 44.1) in an indirect immunofluorescence assay. Gamma interferon did not induce FcRI in the nonresponder monocytes (Fig. 5). Responder monocytes incubated in gamma interferon were stained more intensively with the anti-FcRI antibodies than monocytes incubated in medium alone. Similar results were obtained when monocytes were cultured for $7 \mathrm{~d}$ (in which case gamma interferon was added on day 0 and on day 5) (not shown). Neutrophils have

\section{A CONTROL SUBJECT}

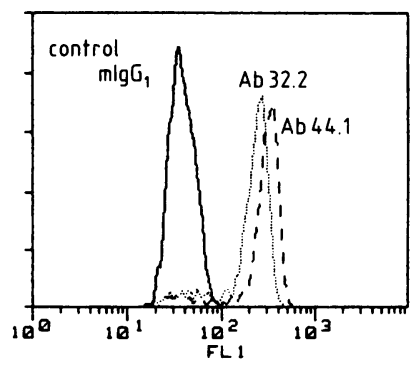

B $\mathrm{OKT}_{3}$ - NONRESPONDER

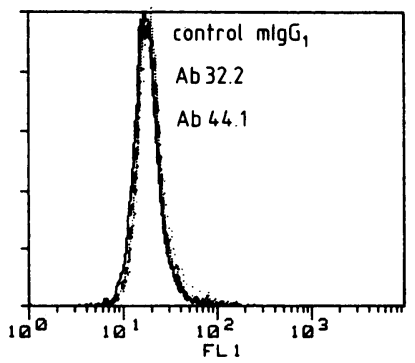

Figure 4. Staining of human monocytes with monoclonal antibodies to FCRI (Ab 32.2 and Ab 44.1). E-rosette-negative cells were first incubated in PBS-BSA, alone or with a control mIgG1, with Ab 32.2 or with $\mathrm{Ab}$ 44.1. After washing, FITC-conjugated $\mathrm{F}\left(\mathrm{ab}^{\prime}\right)_{2}$ fragments of goat anti-mouse $\operatorname{IgG}(50 \mu \mathrm{l}$ of a $1 / 40$ dilution) were used as second label antibodies. After $30 \mathrm{~min}$ incubation at $4^{\circ} \mathrm{C}$, cells were washed twice and analyzed on a FACS as explained in the legend to Fig. 1. No binding of the control mIgG1 was detected. $(A)$ Cells from control subject; $(B)$ cells from OKT3-nonresponder. 

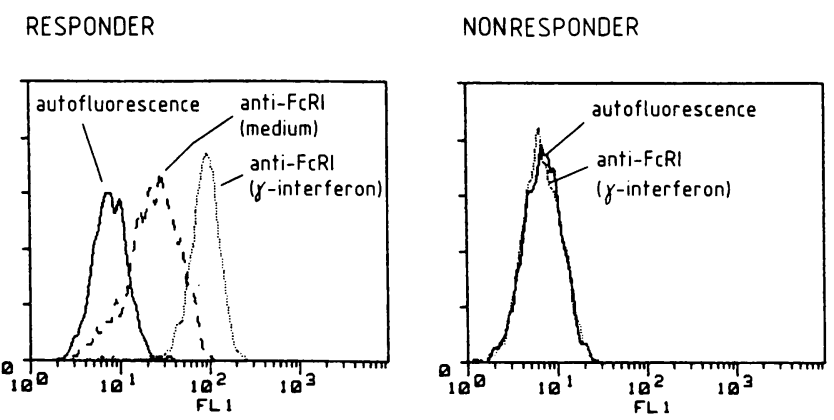

Figure 5. Gamma interferon does not induce FcRI expression in nonresponder monocytes. E-rosette-negative cells $\left(10^{6} / \mathrm{ml}\right)$ from control (responder) subjects and from OKT3-nonresponders were cultured in complete medium with $12 \%$ NHS for $48 \mathrm{~h}$ in Teflon jars, in the presence or absence of recombinant gamma interferon (100 $\mathrm{U} / \mathrm{ml}$ ). Cells were then washed and stained with Ab 32.2 and FITCconjugated $\mathrm{F}\left(\mathrm{ab}^{\prime}\right)_{2}$ goat anti-mouse IgG (as explained in the legend to Fig. 4). Control monocytes incubated in gamma interferon expressed more FcRI than monocytes incubated in medium. However, nonresponder monocytes did not stain with anti-FcRI whether incubated in medium or in gamma interferon.

been shown to express FcRI after incubation for $18 \mathrm{~h}$ with gamma-interferon (7, 32). After incubation overnight with 100 $\mathrm{U} / \mathrm{ml}$ of gamma interferon, neutrophils from responders stained positively with both Ab 32.2 and 44.1, while neutrophils from the four nonresponders were completely negative (Fig. 6). These results demonstrate that the FcRI defect was not restricted to the mononuclear phagocyte lineage.

Phagocytosis of IgG-coated SRBC. To study FcR-mediated phagocytosis, we incubated unopsonized or IgG-sensitized SRBC with monocytes from responder subjects and from nonresponders. As can be seen in Fig. 7, the number of particles phagocytosed per monocyte per hour was not different between responders and nonresponders. Even at low SRBC/ monocyte ratios, or when the SRBC were opsonized with suboptimal doses of the antiserum, no difference between the two groups was detected (not shown). Ab IV.3 (anti-FcRII) almost completely blocked phagocytosis by nonresponder monocytes but not by responder monocytes (Fig. 8). This indicates that in
RESPONDER

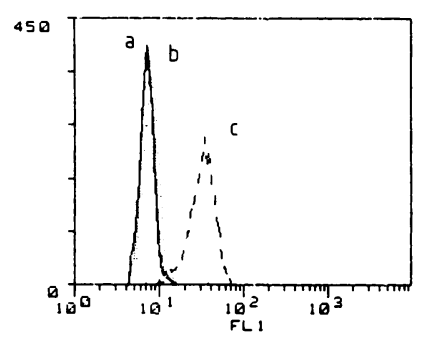

NONRESPONDER

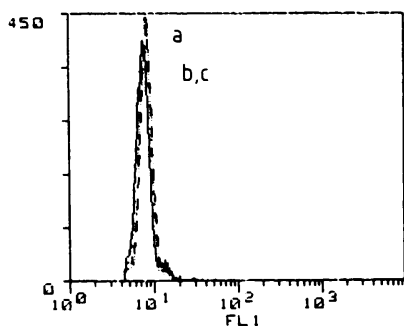

Figure 6. Expression of FcRI on neutrophils after incubation with gamma interferon. Neutrophils $\left(10^{6} \mathrm{cells} / \mathrm{ml}\right)$ were incubated overnight in medium alone, or with $100 \mathrm{U} / \mathrm{ml}$ of gamma interferon. The expression of FcRI was then examined by staining with anti-FcRI antibody 44.1. (a) neutrophils stained with the second label antibody alone (FITC-conjugated $\mathrm{F}\left(\mathrm{ab}^{\prime}\right)_{2}$ fragments of goat anti-mouse IgG). (b) Neutrophils incubated in medium and stained with Ab 44.1 and the second label antibody. (c) Neutrophils incubated in gamma interferon and stained with $\mathrm{Ab} 44.1$ and the second label antibody.

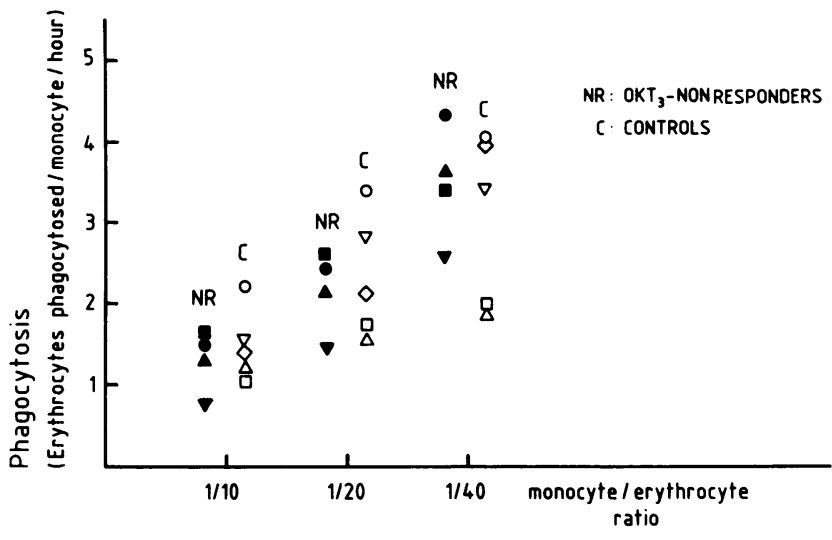

Figure 7. FcR-mediated phagocytosis of IgG-coated SRBC by monocytes from control (responder) subjects (open symbols) and OKT3nonresponders (closed symbols). PBMC, adjusted to a concentration of $5 \times 10^{6}$ monocytes per $\mathrm{ml}$, were incubated at $37^{\circ} \mathrm{C}$ in complete medium with $10 \%$ FCS for $1 \mathrm{~h}$ with a $200-\mu \mathrm{l}$ volume of ${ }^{51} \mathrm{Cr}$-labeled SRBC, either sensitized (rabbit anti-SRBC antibodies) or unsensitized, at different monocyte/erythrocyte ratios. After incubation, nonphagocytosed SRBC were lysed with ammonium chloride in TRIS buffer and the cells were washed twice. Monocyte associated ${ }^{51} \mathrm{Cr}$ was counted in a gamma-scintillation counter and the number of sensitized SRBC phagocytosed per monocyte was calculated.

nonresponder monocytes, phagocytosis was completely mediated by FcRII, while in responders, both FcRI and FcRII were responsible for ingestion of the IgG-coated particles.

Effect of the FcRI defect on other immune functions. All four nonresponder subjects had normal serum levels of $\operatorname{IgA}$, IgG, and IgM. None of them had circulating rheumatoid factors (Latex agglutination test), or anti-nuclear antibodies. Anti-thyroid cytoplasma antibodies were detected in low titer $(1 / 80)$ in the serum of one of the subjects, without evidence of thyroid dysfunction (normal T3 and T4 thyroid hormone and thyroid stimulating hormone levels). No antiparietal cell antibodies, antimitochondrial antibodies, antismooth-muscle antibodies or antistriped muscle antibodies were detected in any of the subjects. No circulating immune-complexes were detected. Peripheral blood lymphocytes normally proliferated in vitro in response to four different common exogeneous antigens (stimulation index $>10$ to at least three of the four anti-

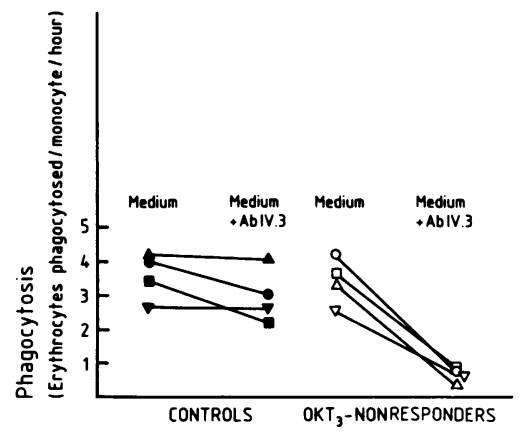

Figure 8. Effect of $\mathrm{Ab}$ IV.3 (anti-FcRII) on FcR-mediated phagocytosis of IgG-coated SRBC. The phagocytosis assay was carried out with monocytes from responder (control) subjects and from nonresponders as explained in the legend to Fig. 7 at a monocyte/SRBC ratio of $1 / 40$. However,

before addition of SRBC, the monocytes in a $120-\mu l$ vol were incubated at $4^{\circ} \mathrm{C}$ with medium alone or with $20 \mu$ l of Ab IV.3 (hybridoma supernatant) for $30 \mathrm{~min}$. Ab IV.3 blocked phagocytosis by nonresponder monocytes, but only partially reduced phagocytosis by responder (control) monocytes. 
Table I. Anti-HB-s Ag Antibody Response after Vaccination*

\begin{tabular}{lcc}
\hline & \multicolumn{2}{c}{$\begin{array}{c}\text { Serum anti-HBs-antibody titer } \\
\text { (IU/liter) }\end{array}$} \\
\cline { 2 - 3 } \multicolumn{1}{c}{ Time of sampling } & Nonresponder & Controls \\
\hline Prevaccination & 0 & 0 \\
1 mo after third vaccination & 700 & $372^{\ddagger}$ \\
Before booster injection & 280 & Not done \\
1 mo after booster & 35,990 & Not done
\end{tabular}

* Antibody titers were determined with the commercial Abbott assay and are expressed in international units per liter. For primo-vaccination, three vaccine doses were given with a 1-mo interval. Booster injection was given 12 mo later.

¥ Geometric mean of antibody titers in a control group of 25 medical students (aged 20-30).

${ }^{\S}$ The geometric mean of anti-HBs titer (determined with the Abbott assay) $1 \mathrm{mo}$ after booster injection, was reported to be 12,313 IU/ liter in a study by Courouce, A.M., A. Laplanche, E. Benhamou, P. Jungers, J. Crosnier, and F. Degos, presented at the "Hepatitis B vaccine symposium: new findings and perspectives" in Bern (Switzerland), 5 September 1984. In this study, Hevac B booster injection was given to 152 medical staff members of hemodialysis units.

gens used) indicating a normal antigen presenting capacity of the monocytes. There was a normal distribution of lymphocyte subpopulations (T4, T8, NK, and B) in peripheral blood. One of the nonresponders was vaccinated with hepatitis $B$ surface antigen and had a normal primary and secondary antibody response (Table I).

\section{Discussion}

The present paper describes a new defect of FcRI on phagocytic cells in four healthy subjects. Our previous reports on the unresponsiveness of $\mathrm{T}$ cells to the monoclonal antibody OKT3 in cultures of PBMC from these subjects had already made it clear that their monocytes were unable to bind the Fc portion of $\mathrm{mIgG} 2 \mathrm{a}(23,24)$. The experiments presented here demonstrate that the underlying abnormality is a defect of monocyte FcRI expression. This was demonstrated with three different assays: binding of monomeric mIgG2a-FITC and HuIgGFITC as analyzed with a FACS, binding of radioactive ligand $\left({ }^{125} \mathrm{I}-\mathrm{HuIgG}\right)$ and rosette formation with anti-D-coated $\mathrm{Hu}$ $\mathrm{RBC}$. The results are compatible with the conclusion that the receptor is either absent or is structurally altered and unable to bind HuIgG and mIgG2a. The fact that two monoclonal antibodies, detecting different epitopes on FcRI, did not stain the nonresponder monocytes, supports (but does not yet prove) the hypothesis of absence (rather than structural alteration) of the receptor. It is not possible to be entirely sure that there is not a small finite number of receptors beyond the capacity of the assays to enumerate. We have shown that the FcRI defect was not restricted to the mononuclear phagocytic cell lineage, but that neutrophils (after preincubation with gamma interferon) were also unable to express the FcRI. Still, this does not exclude the possibility that the FcRI defect is a developmental one. It would therefore have been interesting to study tissue macrophages of these nonresponder subjects (e.g., obtained by bronchoalveolar lavage). Unfortunately, this was not possible. It is highly unlikely that the nonresponder monocytes have a variant FcRI with low affinity for IgG, because aggregated IgG also did not bind to the monocytes after blockade of FcRII with Ab IV.3. The finding that no cytophilic IgG was detected on freshly isolated nonresponder monocytes excludes the possibility that the FcRI was blocked by binding of immune complexes.

The findings could be explained by a major mutational change in the structure of the receptor resulting in inability to bind IgG, and lack of expression of the epitopes recognized by Ab32.2 and 44.1. Alternatively, we might consider the possibility that the gene for FcRI is deleted or not expressed. We found that gamma-interferon did not induce FcRI expression in nonresponder monocytes, which argues against a regulatory defect in FcRI expression. Studies using the appropriate DNA-probes might help us to delineate more accurately the molecular basis of the FcRI defect.

Inability to bind mIgG2a in the nonresponder subjects underlies the lack of monocyte helper function in the support of mIgG2a anti-CD3 induced $\mathrm{T}$ cell mitogenesis. Indeed, interaction of anti-CD3 with both the CD3 molecule on the T cell, and with an FcR on the monocyte, is an essential requirement for $T$ cell activation with anti-CD3 (25). Until now these subjects are the only OKT3-nonresponders described, while unresponsiveness to $\mathrm{mIgG} 1$ anti-CD3 antibodies (e.g., anti-Leu 4) is frequent ( $\sim 30 \%$ of Caucasians). It has to be emphasized that the underlying defect of nonresponders to mIgG2a-antiCD3 is quite different from that of mIgG1-anti-CD3 nonresponders. Monocytes of the latter group of nonresponders are unable to bind the Fc part of mIgGl to FcRII (34). This is not due to the absence of FcRII, but rather to a genetically determined dimorphism of the FcRII, as demonstrated by isoelectric focusing experiments on isolated FcRII molecules (35). The alleles of both variants are about equally distributed in the population. Since only one of the two variant forms is able to bind mIgG1 (while both can bind complexed HuIgG), homozygotes for the type of FcRII that is unable to bind $\mathrm{mIgG} 1$ will be nonresponders to $\mathrm{mIgG1}$ anti-CD3. This has no implications for their mononuclear phagocytic system in view of the apparent normal ability of this variant of FcRII to bind complexed HuIgG. The defective expression of phagocyte FcRI in the subjects described in this paper is thus a different situation. One would expect the absence of functional FcRI to be associated with a severe immune defect (16-22). Surprisingly, these monocytes normally ingested (even suboptimally opsonized) IgG-coated SRBC, and this was exclusively mediated through FcRII, as demonstrated by the blocking experiments with Ab IV.3. Based on immunofluorescence intensity obtained with Ab IV.3, the density of FcRII did not appear to be increased on nonresponder monocytes. The monocytes (similar to control monocytes) also did not express detectable levels of FcRIII. Thus a compensatory increase in FcRII density or an unusual expression of FcRIII did not account for normal phagocytosis. The lack or functional incompetence of monocyte FcRI also has not resulted in any clinical pathology. No circulating immune complexes were detected, no autoimmune pathology was present, and the specific antibody response (primary and secondary) to a viral antigen were completely normal. These latter experiments were carried out in view of the data that FcRI might be involved in antigen presentation via membrane bound antibodies $(19,20)$. It thus appears that FcRI might not be essential for survival, and perhaps does not have an important role in body defenses. It is also possible that 
FcRI is important, but that most functions of FcRI were taken over in this particular situation of nonresponder subjects by the other FcRs. FcRII and FcRIII, although they have low affinity for monomeric IgG, can efficiently bind immune complex or particle-bound $\operatorname{IgG}(4,33)$. Clarkson et al. injected an anti-FcRIII antibody in primates. They observed that this antibody prolonged in vivo clearance of model immune complexes from an initial clearance half-time of $90 \mathrm{~min}$ to 4,095 min immediately after infusion (36). These results stress the dominant importance of FcRIII for removal of immune complexes in vivo. FcRIII is expressed on two types of phagocytic cells: neutrophils and macrophages (but not monocytes) (11). Moreover, complement receptors on the monocytes and the macrophages may also be important in the removal of immune complexes (37). C3bi receptors, similar to FcRII and FcRIII receptors, are normally present on the phagocytic cell membranes of the four subjects described here. All this probably explains when they had normal immune function in spite of a major FcR defect, restricted however to only one type of FcR.

Apart from the description of a unique FcRI defect, our data also provide some additional information on monocyte FcR function. It has never been unequivocally demonstrated before that FcRII on monocytes can mediate phagocytosis of IgG-coated particles. This is due to inability of blocking specifically FcRI function, while leaving FcRII intact. The results obtained with nonresponder monocytes now clearly demonstrate that FcRII indeed can mediate phagocytosis independently. The data also unequivocally demonstrate that normal FcRI function is required for binding of monomeric HuIgG and $\mathrm{mIgG} 2 \mathrm{a}$ to monocytes, and that the cytophilic $\mathrm{IgG}$ on circulating monocytes from healthy subjects is fixed by FcRI. The findings should stimulate further work on the differential function and relative importance of the distinct types of FcRs on phagocytic cells.

\section{Acknowledgments}

We are grateful to the members of the OKT3-nonresponder family for their cooperation and blood donations. We also thank Prof. J. Desmyter (Laboratory of Virology, University Hospital and Rega Institute, University of Leuven, Belgium) for determination of hepatitis B-surface antibodies; Professor B. Van Camp and Dr. M. Dewaele (Division of Immunology, Free University of Brussels, Brussels) for the use of the FACS-Star in their laboratory; and Ria Timmermans for secretarial assistance in the preparation of this manuscript.

This work was supported by a grant from the Belgian National Fund for Scientific Research (1.5.386.87N).

\section{References}

1. Anderson, C. L., and R. J. Looney. 1986. Human leucocyte IgG Fc receptors. Immunology Today. 7:264-266.

2. Anderson, C. L. 1982. Isolation of the receptor for IgG from a human monocyte cell line (U937) and from human peripheral blood monocytes. J. Exp. Med. 156:1794-1805.

3. Anderson, C. L., P. M. Guyre, J. C. Whitin, D. H. Ryan, R. J. Looney, and M. W. Fanger. 1986. Monoclonal antibodies to Fc receptors for IgG on human mononuclear phagocytes. Antibody characterization and induction of superoxide production in a monocyte cell line. J. Biol. Chem. 261:12856-12864.

4. Looney, R. J., G. N. Abraham, and C. L. Anderson. 1986. Human monocytes and U937 cells bear two distinct Fc receptors for IgG. J. Immunol. 136:1641-1647.
5. Fries, L. F., R. P. Hall, T. J. Lawley, G. R. Crabtree, and M. M. Frank. 1982. Monocyte receptors for the Fc portion of IgG studied with monomeric HuIgG1: Normal in vitro expression of Fc gammareceptors in HLA-B8/DRw 3 subjects with defective Fc-gamma-mediated in vivo clearance. J. Immunol. 129:1041-1049.

6. Anderson, C. L., and G. N. Abraham. 1980. Characterization of the Fc receptor for IgG on a human macrophage cell line U937. $J$. Immunol. 125:2735-2741.

7. Perussia, B., E. T. Dayton, R. Lazarus, V. Fanning, and G. Trinchieri. 1983. Immune interferon induces the receptor for monomeric IgGI on human monocytic and myeloid cells. J. Exp. Med. 158:1092-1113.

8. Looney, R. J., D. H. Ryan, K. Takahashi, H. B. Fleit, H. J. Cohen, G. N. Abraham, and C. L. Anderson. 1986. Identification of a second class of IgG Fc receptors on human neutrophils. A 40-kD molecule found also on eosinophils. J. Exp. Med. 163:826-836.

9. Rosenfeld, S. I., R. J. Looney, J. P. Leddy, D. C. Phipps, G. N. Abraham, and C. L. Anderson. 1985. Human platelet Fc receptor for immunoglobulin G. Identification as a 40,000 molecular weight membrane protein shared by monocytes. J. Clin. Invest. 76:23172322.

10. Moretta, L., S. R. Webb, C. E. Grossi, P. M. Lydyard, and M. D. Cooper. 1977. Functional analysis of two human T cell subpopulations. Help and suppression of B-cell responses by $\mathrm{T}$ cells bearing receptors for IgM or IgG. J. Exp. Med. 146:184-200.

11. Fleit, H. B., S. D. Wright, and J. C. Unkeless. 1982. Human neutrophil Fc-gamma-receptor distribution and structure. Proc. Natl. Acad. Sci. USA. 79:3275-3279.

12. Perussia, B., G. Trinchieri, A. Jackson, N. L. Warner, J. Faust, H. Rumpold, D. Kraft, and L. L. Lanier. 1984. The Fc receptor for IgG on human natural killer cells: phenotypic, functional and comparative studies with monoclonal antibodies. J. Immunol. 133:180-189.

13. Lanier, L. L., T. J. Kipps, and J. H. Phillips. 1985. Functional properties of a unique subset of cytotoxic CD3 (+) T-lymphocytes that express Fc receptors for IgG (CD16/Leu 11 antigen). J. Exp. Med. 162:2089-2106.

14. Jones, D. H., R. J. Looney, and C. L. Anderson. 1985. Two distinct classes of IgG Fc receptors on a human monocyte line (U937) defined by differences in binding of murine IgG subclasses at low ionic strength. J. Immunol. 135:3348-3353.

15. Lubeck, M. D., Z. Steplewski, F. Baglia, M. H. Klein, K. J. Dorrington, and H. Koprowski. 1985. The interaction of murine IgG subclass proteins with human monocyte Fc receptors. J. Immunol. 135:1299-1304.

16. Lawley, T. J., R. P. Hall, A. S. Fauci, S. I. Katz, M. I. Hamburger, and M. M. Frank. 1981. Defective Fc receptor function associated with the HLA-B8/DRw 3 haplotype: studies in patients with Dermatitis Herpetiformis and normal subjects. N. Engl. J. Med. 304:185-192.

17. Salmon, J. E., R. P. Kimberly, A. Gibofsky, and M. Fotino. 1984. Defective mononuclear phagocyte function in systemic lupus erythematosus: dissociation of $\mathrm{Fc}$ receptor ligand binding and internalisation. J. Immunol. 133:2525-2531.

18. Salmon, J. E., R. P. Kimberly, A. Gibofsky, and M. Fotino. 1986. Altered phagocytosis by monocytes from HLA-DR2 and DR3positive healthy adults is Fc-gamma-receptor specific. J. Immunol. 136:3625-3630.

19. Celis, E., and T. W. Chang. 1984. Antibodies to Hepatitis B surface antigen potentiate the response of human T-lymphocyte clones to the same antigen. Science (Wash. DC). 224:297-299.

20. Celis, E., V. R. Zurawski, and T. W. Chang. 1984. Regulation of T-cell function by antibodies: enhancement of the response of human T-cell clones to hepatitis B surface antigen by antigen-specific monoclonal antibodies. Proc. Natl. Acad. Sci. USA. 81:6846-6850.

21. Van Boxel, J. A., J. D. Stobo, W. E. Paul, and I. Green. 1972. Antibody dependent lymphoid cell-mediated cytotoxicity. No requirement for thymus derived lymphocytes. Science (Wash. DC). 175:194196. 
22. Zighelboim, J., B. Bonavida, and J. L. Fahey. 1973. Evidence for several cell populations active in antibody-dependent cellular cytotoxicity. J. Immunol. 111:1737-1742.

23. Ceuppens J. L., L. Meurs, and J. P. Van Wauwe. 1985. Failure of OKT3 monoclonal antibody to induce lymphocyte mitogenesis: a familial defect in monocyte helper function. J. Immunol. 134:14981502.

24. Ceuppens, J. L., F. J. Bloemmen, and J. P. Van Wauwe. 1985. T-cell unresponsiveness to the mitogenic activity of OKT3 antibody results from a deficiency of the monocyte Fc-gamma receptors for murine IgG2a and inability to cross-link the T3-Ti complex. J. Immunol. 135:3882-3886.

25. Clement, L. T., A. B. Tilden, and N. E. Dunlap. 1985. Analysis of the monocyte Fc receptors and antibody-mediated cellular interactions required for the induction of T-cell proliferation by anti-T3 antibodies. J. Immunol. 135:165-171.

26. Wright, S. D., P. E. Rao, W. C. Van Voorhis, L. S. Craigmyle, K. Iida, M. A. Talle, E. F. Westberg, G. Goldstein, and S. C. Silverstein. 1983. Identification of the $\mathrm{C} 3 \mathrm{bi}$ receptor of human monocytes and macrophages by using monoclonal antibodies. Proc. Natl. Acad. Sci. USA. 80:5699-5703.

27. Ceuppens, J. L., J. S. Goodwin, and R. P. Searles. 1981. The presence of Ia antigen on human peripheral blood T-cells and T-cell subsets. Analysis with monoclonal antibodies and the fluorescence activated cell sorter. Cell. Immunol. 64:277-292.

28. Bigazzi, P. E., C. L. Burek, and N. R. Rose. 1986. Antibodies to tissue-specific endocrine, gastrointestinal and neurological antigens. Manual of Clinical Laboratory Immunology. N. R. Rose, H. Friedmann, and J. L. Fahey, editors. American Society for Microbiology, Washington, DC. Third ed. 762-770.

29. Vanham, G., F. J. Bloemmen, J. L. Ceuppens, and E. A. M. Stevens. 1984. Influence of immune complex size and antigen-anti- body ratio on immune complex detection with monoclonal rheumatoid factor and Clq. J. Clin. Lab. Immunol. 15:63-68.

30. Van de Winkel, J. G. J., W. J. M. Tax, M. C. J. Van Bruggen, C. E. P. Van Roozendaal, H. W. Willems, A. Vlug, P. J. A. Capel, and R. A. P. Koene. 1987. Characterization of two Fc receptors for mouse immunoglobulines on human monocytes and cell lines. Scand. J. Immunol. 26:663-672.

31. Guyre, P., P. M. Morganelli, and R. Miller. 1983. Recombinant immune interferon increases immunoglobulin G Fc receptors on cultured human mononuclear phagocytes. J. Clin. Invest. 72:393-397.

32. Shen, L., P. M. Guyre, and M. W. Fanger. 1987. Polymorphonuclear leucocyte function triggered through the high affinity Fc receptor for monomeric IgG. J. Immunol. 139:534-538.

33. Tax, W. J. M., F. F. M. Hermes, R. W. Willems, P. J. A. Capel, and R. A. P. Koene. 1984. Fc receptors for mouse IgG1 on human monocytes: polymorphism and role in antibody-induced T-cell proliferation. J. Immunol. 133:1185-1189.

34. Ceuppens, J. L., and F. Van Vaeck. 1987. Direct demonstration of binding of anti-Leu 4 antibody to the $40 \mathrm{kDa} \mathrm{Fc}$ receptor on monocytes as a prerequisite for anti-Leu4-induced $\mathrm{T}$ cell mitogenesis. $J$. Immunol. 139:4067-4071.

35. Anderson, C. L., D. H. Ryan, R. J. Looney, and P. C. Leary. 1987. Structural polymorphism of the human monocyte $40 \mathrm{Kd} \mathrm{Fc}$ receptor for IgG. J. Immunol. 138:2254-2256.

36. Clarkson, S. B., R. P. Kimberly, J. E. Valinksky, M. D. Witmer, J. B. Bussel, R. L. Nachman, and J. C. Unkeless. 1986. Blockade of clearance of immune complexes by an anti-Fc gamma-receptor monoclonal antibody. J. Exp. Med. 164:474-489.

37. Mantovani, B., M. Rabinovitch, and V. Nussenzweig. 1972. Phagoytosis of immune complexes by macrophages. Different role of the macrophage receptor sites for complement (C3) and for immunoglobulin (IgG). J. Exp. Med. 135:780-792. 